\title{
CONCEPT FORMATION IN THE SPEAKING AUTISTIC CHILD
}

\author{
Marlene Noach, B.A., SP. \& H.TH. (Rand) \\ Department of Speech Pathology and Audiology, University of the \\ Witwaterstand, Johannesburg
}

Examination of the case histories of speaking austistic children reveals instances of compulsive concreteness in thought and action. Their global intellectual functioning, their perception and their language in particular, seem to reflect a disturbance in the capacity for concept formation.

They are known for their "islets of intelligence" against a background of serious retardation. ${ }^{2} \mathrm{Kanner}^{9}$ has indicated that their "striking physiognomies" relate to their excellent rote memory for poems and names, and the precise recollection of complex patterns and sequences. These activities are essentially concrete and are used in a stereotyped and compulsive manner. Goldstein and Scheerer ${ }^{4}$ have shown that this type of behaviour is indicative of an impairment in abstract attitude.*

The abnormal perceptual experience of autistic children - their characteristic "visual and auditory avoidance" 16 further supports speculation regarding a disturbance in concept formation, which occupies a higher level than perception in the hierarchies of experience.

Many aspects of their language further support this postulation, such as the lack of spontaneous utterances and their echolalia. The latter may well be interpreted as "stereotyped attempts to assimilate experience successfully" as proposed by Myklebust. ${ }^{11}$ Their echolalia may be regarded as a mechanism used for coping with their inability to assimilate language in its symbolic meaning.

Kanner ${ }^{6}$ has spoken of the "literalness" characteristically present in their language. Some apt examples should illustrate this:

One child learned to say "yes" when his father told him that he would put him on his shoulders if he said "ves". This word then came to mean and express only the desire to be put on his father's shoulders. ${ }^{6}$

John $\mathbf{F}$. corrected his father's statement about pictures "on the wall"- the pictures were "near the wall".20

It is apparent that meaning can only be used with reference to the original acquired connotation. This is again displayed in their "metaphorical expressions"- an apparent discrepant characteristic in the

\footnotetext{
*Abstract attitude implies the conscious and volitional activity of abstracting common from particular properties and synthesizing these. The individual thing represents a concept or category.
} 
clinical picture. Kanner" was able to trace these "irrelevant phrases" to their original sources and to learn that these peculiar expressions, out of place in ordinary conversation, assume definite meaning. From the following evidence, one may infer that concepts are well within the autistic child's scope :

Gary T. at five years, designated a bread basket as "home bakery". He did not stop there. After this, every basket to him became a "home bakery".

Their conceptual ability, however, becomes questionable when one considers the case of "Idiot Savant", whose case history is similar in a number of aspects to that of children with early childhood autism. Scheerer, Rothmann and Goldstein ${ }^{13}$ proposed that this child produced abstract words in the "situational sense of his concrete realism", rather than in their abstract meaning. This would appear to be the more logical interpretation of the irrelevant and metaphorical utterances of the autistic children, so that it could be speculated that they are in fact functioning at an extremely concrete level.

Rutter ${ }^{12}$ has reported a number of experiments carried out by Hermelin and $O^{\prime}$ Connor in which they examined the coding and immediate recall in autistic subjects. These children did not use concepts or association in memorizing words as did the normal subjects. In addition, it was found that autistic children were more likely to remember nonsense phrases than normal children, so that it was concluded that their verbal recall was independent of meaning.

Since no studies known to the writer have been conducted to experimentally investigate the concept formation in autistic children, it was felt that such a study could yield useful information which could have important implications for a wide range of behaviour.

\section{METHOD}

The aim of this investigation was to determine the structure of concept formation on different levels of its development in speaking autistic children. The data will be discussed in relation to that of a group of normal children selected to form a basis for comparison. The test used was modelled on a test suggested by Hanfmann and Kasanin ${ }^{5}$, who are ardent followers of Vygotsky. They modified and standardized the methods used by Vygotsky in his many valuable studies of concept formation.

\section{Subjects}

The experimental group consisted of four female, speaking autistic children of different ages. These subjects were selected in terms of the following criteria :

(a) Diagnosis of autism by a psychiatrist. Subjects who developed autism as a result of any disease process were not included in this study. 
(b) The presence of speech, regardless of peculiarities.

(c) Case histories indicating one of Kanner's two premises for a diagnosis of early childhood autism. These have been universally accepted as the two cardinal features of autism-

(i) an inability to relate to people in an ordinary way;

(ii) insistence on the preservation of sameness and sustained resistance to change.

The comparative group of normal children was matched in pairs as closely as possible for chronological age, sex, socio-economic status, and language medium. The subjects were not matched for intelligence and the writer is aware of the severe limitation this poses to an accurate comparison of the two groups. However, I.Q. scores could not be taken into account as those available for the autistic children were particularly noted for their unreliability.

The age range was 8 years 9 months to 14 years 4 months. (Table 1.)

\section{Materials}

The materials consisted of 22 cardboard blocks varying in a number of aspects, viz. colour, shape, height and size. (Figure 1.)

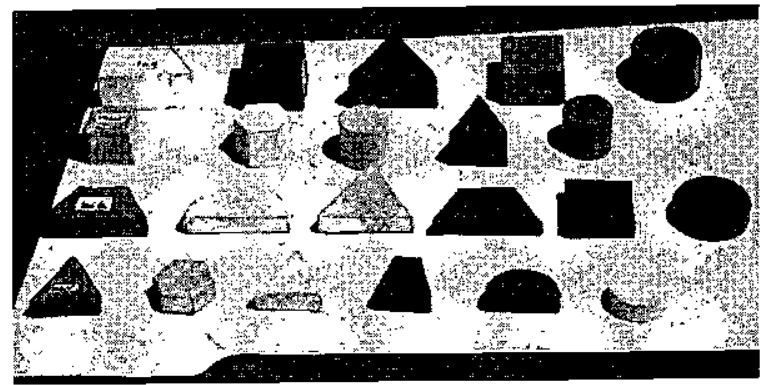

Figure 1. Organization of blocks to illustrate their different attributes

One of four, nonsense syllables (lag, mur, bik, cev) was written on the underside of each block which was not visible to the subject. Regardless of colour, "lag" was written on all large, tall blocks, "bik" on all large, flat blocks, "mur" on all small, tall blocks and "cev" on the small, flat ones.

It is thus apparent that the materials provided the perceptual experience necessary for the abstraction of traits, as well as the word, which the Soviet Psychologists believe to be essential in aiding the process of concept formation.

The aim of the test was for the subjects to classify the blocks according to height and size, ignoring the other aspects.

At the beginning of the test, all the blocks, well-distributed as to colour and size, were arranged on the circular area of a square board, the remainder of which was divided into four spaces. (Figure 2.) 
The subject was told that there were four different kinds of blocks and that each kind had a name. Each kind was to be sorted into a separate comer space. The experimenter turned up one of the blocks, exposed its name to the subject and suggested that he select those blocks which he thought might belong to the same kind. After he had done so, the experimenter exposed one of the incorrectly selected blocks, stated that it was a block of a different kind and that it had a different name and suggested further attempts at the task. The correction process was repeated after each new attempt, until either the principle of

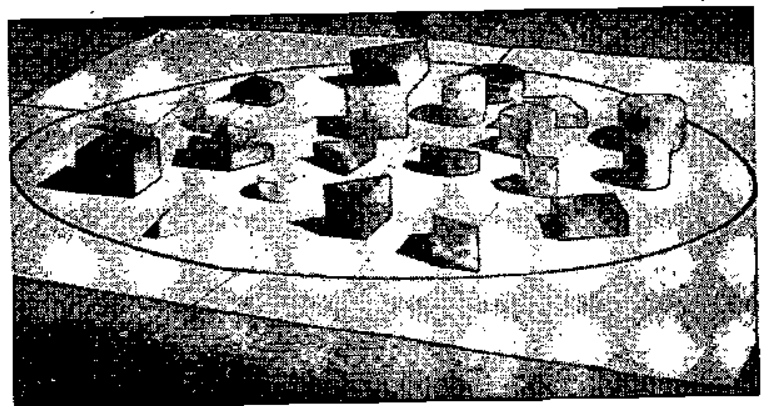

Figure 2. Presentation of Blocks at the Beginning of the Test.

classification was discovered, or the blocks were classified through all having been turned up by the experimenter. It is thus evident that in the task, word-meaning developed. The word which was originally a nonsense word came to represent certain characteristics in the blocks, i.e. the word" represented the desired concept.

This test was felt to be particularly suitable for use with autistic children since it allowed a freedom of procedure on the part of the subjects. Furthermore, its value lies in a detailed qualitative analysis of their performance. Many examiners who have attempted to investigate the behavioural and cognitive aspects of autistic children have terminated their investigations with the bland statement; "This child is untestable". This has been particularly the case with tests scored according to a pass/fail dichotomy. This test does not rely on quantitative measures.

\section{PROCEDURES}

\section{Administration of the test}

The test was administered individually to each subject in the appropriate language medium. A number of additional techniques were used in testing the autistic children,. for example, "techniques of structure" or "adaptive teaching techniques". These have been recommended by an American investigator, Davis, ${ }^{3}$ who used them for an appraisal of the language and learning behaviour of autistic children. The technique involves the controlling of stimulus modalities by blocking others that might interfere, e.g. subject's eyes are covered while the experimenter 
talks directly into her ear, or the experimenter cups her hands on the sides of the child's face, blocking the peripheral vision, so that the child can look only where directed.

In view of the autistic child's preference for the proximal senses, they were encouraged to hold and feel the blocks so as to facilitate better identification.

Testing was often lengthy but no breaks were given during testing. Sweets were used for motivation.

A tape recording was made of the entire testing procedure. An independent observer made detailed records of the corrections made by the experimenter and the selections made by the subjects. The tape recordings and written record were then combined for purposes of analysis.

\section{Ranking of the subjects}

Before the data was analysed, the autistic children were ranked in order of the severity of their autism from 1, the clinically most severely affected child, to 4 , the clinically most normal child. This ranking procedure was adopted in order to compare the severity of autism with the level of conceptual attainment.

\section{Analysis}

The independent records of each child were analysed qualitatively according to Vygotsky's ${ }^{15}$ developmental stages in the ascent to concept formation. These range from syncretic thinking, through complex thinking with its various levels of complex formation, to true conceptual thinking. Bruner and Olver's" "multiple grouping complex" was applied to the test performance of subject Al. (Table 1.)

\section{RESULTS AND DISCUSSION}

Due to the length of the records of subjects, a schematic representation of each subject's performance will be provided. (Table 1.) The subjects are presented in order of the ranking - of the autistic subjects.

It may be seen that the autistic group is uniformly inferior to the normal.

(i) Each autistic subject was at a more primitive stage in the development of conceptual ability than the normal subject.

(ii) The entire group of autistic subjects displayed syncretic thinking at one stage or another, whereas there was an absence of the formation of a syncretic image in the normal group.

Syncretic thinking is displayed in the experimental task when the subject places a number of unrelated blocks randomly in one group or by virtue of their spatial position on the board: ${ }^{15}$ 
(iii) At no stage during the experiment did the autistic children adopt a conceptual procedure. The entire group of normal children showed a capacity for conceptual thinking.

It is further evident that both groups used complex thinking at one stage or another. Complex thinking is a more objective type of thinking than syncretic. It is objective in that bonds are observed in the experimental material, but it is differentiated from the conceptual approach by the fact that these bonds are concrete and factual rather than abstract and logical. ${ }^{15}$

\begin{tabular}{|c|c|c|c|}
\hline \multicolumn{2}{|r|}{ Autistic } & \multirow[b]{2}{*}{$\begin{array}{l}\text { N.1 } \\
\text { Age: } \\
11.6\end{array}$} & Normal \\
\hline $\begin{array}{c}\text { A.1 } \\
\text { Age: } \\
11.8\end{array}$ & $\begin{array}{l}\text { 1. Syncretism } \\
\text { 2. Multiple grouping complex } \\
\text { 3. Associative complex } \\
\text { 4. Multiple grouping complex }\end{array}$ & & $\begin{array}{l}\text { 1. Genuine concept } \\
\text { 2. Collection complex } \\
\text { 3. Collection complex based on } \\
\text { mixed principles } \\
\text { 4. Potential concept } \\
\text { 5. Genuine concept }\end{array}$ \\
\hline $\begin{array}{l}\text { A.2 } \\
\text { Age: } \\
9.0\end{array}$ & $\begin{array}{l}\text { 1. Syncretism } \\
\text { 2. Syncretism combined with } \\
\text { associative complex } \\
\text { 3. Syncretism }\end{array}$ & $\begin{array}{c}\text { N.2 } \\
\text { Age: } \\
9.0\end{array}$ & $\begin{array}{l}\text { 1. Potential concept } \\
\text { 2. Diffuse complex } \\
\text { 3. Pseudo concept } \\
\text { 4. Diffuse complex } \\
\text { 5. Potential concept }\end{array}$ \\
\hline $\begin{array}{l}\text { A.3 } \\
\text { Age: } \\
14.4\end{array}$ & $\begin{array}{l}\text { 1. Syncretism } \\
\text { 2. Collection complex } \\
\text { 3. Collection based on mixed } \\
\text { principles } \\
\text { 4. Collection complex }\end{array}$ & $\begin{array}{l}\text { N.3 } \\
\text { Age: } \\
14.4\end{array}$ & 1. Genuine concept \\
\hline $\begin{array}{c}\text { A.4 } \\
\text { Age: } \\
8.9\end{array}$ & $\begin{array}{l}\text { 1. Syncretism } \\
\text { 2. Chain complex } \\
\text { 3. Associative complex } \\
\text { 4. Collection complex based on } \\
\text { mixed principles } \\
\text { 5. Collection complex }\end{array}$ & $\begin{array}{c}\text { N.4 } \\
\text { Age: } \\
8.9\end{array}$ & $\begin{array}{l}\text { 1. Potential concept } \\
\text { 2. Genuine concept }\end{array}$ \\
\hline
\end{tabular}

Table 1: Developmental sequence of forms of thinking employed by the subjects in the experimental task

Obvious differences in the usage of complex thinking do exist. In the autistic group, this was the highest phase of development, whereas in the normal group complex thinking preceded the conceptual approach. On the basis of this, it may be concluded that the difference between the two groups is not that the normal group will never use a more primitive procedure, but that they CAN use a conceptual one. The hypothesis of a general disturbance in concept formation may therefore be accepted.

Concerning the nature of the disturbance, the possibility of a developmental delay appears to be negated by the fact that the same phase of concept formation was reached, by the subjects regardless of the age differences. Regression to more primitive stages has been proposed, on the basis of the data, to be related to the severity of the autism 
since progressively more complicated forms of complex formation were used by the clinically more normal children. It seems, therefore, that the nature of the disturbance is an impairment. This may further be substantiated by the fact that Vygotsky ${ }^{14}$ found schizophrenic adults to be incapable of conceptual thinking and to exist at the complex thinking phase of development. If we go along with the early theories that autism may be classified in the psychiatric nosology as the "earliest stage in the development of schizophrenia", 8 then it appears that since both groups exist at the same level of conceptual attainment, that there may be a general impairment of concept formation in the psychiatric disorder.

It was interesting to note and, in fact, this appears to substantiate the findings analysed according to Vygotsky's theory, that the autistic subjects showed the characteristics of "lack of shifting" or "rigidity" in their approach to the task, as well as the characteristic of "extreme susceptibility to stimuli". These characteristics are well-known in braininjured patients. Goldstein and Scheerer ${ }^{4}$ have actually stated that they are a direct result of a concrete attitude.

\section{CONCLUSIONS AND IMPLICATIONS}

On the basis of the data obtained from this investigation, it may be concluded that the autistic children showed an impairment in concept formation, existing at a lower developmental level than the comparative normal group. Findings apply legitimately only to the subjects used in this study due to limitations inherent in the experimental methods. Despite limitations it is felt that the results do give an indication of the problems involved in the development of conceptual skills in speaking autistic children.

It would seem essential in therapy to devise a programme to develop their conceptual abilities. There is a tendency in therapy to teach concepts by the mere association of the word with the object. By viewing conceptualization as the highest point on a continuum, from perception, through abstraction and generalization to conceptualization, it would be illogical to begin with conceptualization.

Therapy should first be directed at improving their perceptual abilities. The children should then be given basic training in the processes of abstraction and generalization. They may be taught to compare objects in terms of their differing attributes, then to sort and classify the common abstracted elements. In an attempt to make their thought processes less rigid, generalizations to new situations should be taught.

By applying this therapy programme, concept formation will be effected by an "active intellectual process"15 guided by the role of language, rather than by the association of verbal symbols and objects which Vygotsky has shown to be insufficient for true concept formation.

A similar study with a more representative sample and a number of subjects at each age level, together with the use of a battery of concept 
formation tests, could yield more conclusive evidence of the findings of this study. Should the findings be substantiated, a further aetiological consideration could be put forward to support an organic theory of early childhood autism. By a study of this kind, we may be given better insight into the cardinal features of autism. Deprived of the organizing role of concepts to give order to their sensations, they cope by withdrawing "to seek comfort in solitude" 8 rather than to exist in a chaotic world of a multitude of stimuli. Conceptualization permits a manipulation of the "hypothetical world". Possessing an impairment in this function of prediction and manipulation of experience, they cope by insisting on the preservation of sameness, resisting change with every effort so as to provide a degree of stability in the face of ever-changing environmental demands.

A further investigation comparing the concept formation of speaking and mute autistic children could provide an indication into the possible existing differences between these two groups in terms of their concept formation. As language has been noted to be an important factor indicating prognosis, so ability for concept formation may possibly be regarded as a further prognostic indicator.

\section{SUMMARY}

The aim of this investigation was to determine the structure of concept formation on different levels of its development in speaking autistic children. A modified form of the Hanfmann-Kasanin Test of concept formation was administered to four female speaking autistic children. A control group was selected for comparative purposes.

It was established by a qualitative analysis according to Vygotsky's theory that the autistic group was uniformly inferior to the normal group in their capacity for concept formation. It was concluded that these children showed an impairment in concept formation.

\section{OPSOMMING}

Die doel van hierdie ondersoek was om die struktuur van konsepvorming op verskillende vlakke van ontwikkeling in outistiese kinders, wat die vermoë besit om te praat, vas te stel. Die Hanfmann-Kasanintoets vir konsepvorming is gewysig en toegepas op vier vroulike, pratende outistiese kinders. 'n Kontrolegroep is geselekteer vir vergelykende doeleindes.

Daar is deur middel van 'n kwalitatiewe analise volgens Vygoțsky se teorie vasgestel dat die outistiese groep as geheel minderwaardig is in hul vermoë tot konsepvorming in vergelyking met die normale groep. Die affeiding is dus gemaak dat hierdie kinders 'n defek toon in konsepvorming.

\section{REFERENCES}

1. Bruner, J. S. and Olver, R. R. (1965): Development of equivalence transformation in children. In Readings in the Psychology of Cognition. Ed. Anderson, R. C; and Ausabel, D. P. Holt, Rinehart and Winston, Inc., New York. 
2. Creak, E. M. (1963): Childhood Psychosis: A review of one hundred cases. British Journal of Psychiatry, 109.

3. Davis, B. J. (1967): A clinical method of the appraisal of language and learning behaviour of young autistic children. Journal of Communication Disorders, 1, 277-296.

4. Goldstein, K. and Scheerer, M. (1941): Abstract and concrete behaviour. An experimental study with special tests. Psychological Monographs, 53:2, $1-149$.

5. Hanfmann, E. and Kasanin, 3. (1937): A method for the study of concept formation. Journal of Psychology, 3, 521-540.

6. Kanner, L. (1944): Early infantile autism. Journal of Paediatrics, 25:2, 211-217.

7. Kanner, L. (1946): Irrelevant and metaphorical language in early infantile autism. American Journal of Psychiatry, 103, 242-246.

8. Kanner, L. (1949): Problems of nosology and psychodynamics of early infantile autism. American Journal of Orthopsychiätry, 19, 416-426.

9. Kanner, L. (1957): Child Psychiatry. Chapter 49. Charles C. Thomas, Publisher, Springfield, Illinois. Third Edition.

10. Kanner, L. and Lesser, L. I. (1958): Early infantile autism. Paediatric Clinics of North America, 5:3, 711-729.

11. Myklebust, H. R. (1957): Babbling and echolatia in language theory. Journal of Speech and Hearing Disorders, 22, 356-360.

12. Rutter, M. (1968): Concepts of autism: A review of research. Journal of Child Psychology and Psychiatry, 9:1, 1-25.

13. Scheerer, M., Rothmann, E. and Goldstein, K. (1945): A case of "Idiot Savant": An experimental study of personality organization. Psychological Monographs, 58:4, 1-61.

14. Vygotsky, L. S. (1934): Thought in schizophrenia. Translated by J. Kasanin. Archives of Neurology and Psychiatry, 31:5, 1063-1077.

15. Vygotsky, L. S. (1962): Thought and Language. The M.I.T. Press.

16. Wing, J. K. (1966): Diagnosis, epidemiology, aetiology. Chapter 1 in Early Childhood Autism: Clinical, Educational and Social Aspects. Ed. Wing, J. K. Pergamon Press, London. 